\title{
Rainfall Trends in the Sudano-Sahelian Ecological Zone of Nigeria
}

\author{
Ifabiyi, I. P. ${ }^{1} \&$ Ojoye, S. ${ }^{2}$ \\ ${ }^{1}$ Department of Geography and Environmental Management, University of Ilorin, Ilorin, Nigeria \\ ${ }^{2}$ Department of Geography, Federal University of Technology, Minna, Nigeria \\ Correspondence: Ifabiyi, I. P., Department of Geography and Environmental Management, University of Ilorin, \\ Ilorin, Nigeria. E-mail: tokunifabiyi@yahoo.com
}

Received: January 15, 2013 Accepted: June 13, 2013 Online Published: July 19, 2013

doi:10.5539/esr.v2n2p194 URL: http://dx.doi.org/10.5539/esr.v2n2p194

\begin{abstract}
The trends of rainfall have a great impact on the hydrologic cycle and therefore affect both the quality and quantity of water resources. There is therefore the need to examine the trend of rainfall in Sudano- Sahelian Ecological Zone of Nigeria comprising Kebbi, Sokoto, Kano, Jigawa, Yobe, Katsina and Borno States. The study examined the trend in rainfall patterns over a period of fifty years i.e. 1960-2009 so as to know the effect of rainfall variability in the occurrence of drought and flood in the zone. The study makes use of rainfall data, which were collected from the Nigeria Meteorological Agency, Oshodi, Lagos. The Standardized Anomaly Index was used to test for fluctuations in rainfall while the Spearman Rank Statistics was used to look for the trend in rainfall. The study revealed that there was a downward trend in rainfall amounts in the 1970s and 1980s which was responsible for the drought episodes of 1972/73 and 1980 and an upward trend in the amount of rainfall between 1990 and 2009 which accounts for the flood episodes in Northern Nigeria. There is a general increase of $5 \%$ in annual rainfall over the entire fifty years under study in the zone due to an observable $5.4 \%$ increase in mean rain-days and $4 \%$ increase in the rains that fall as heavy rain, which was found to be responsible for the increase in runoff, ground water recharge and the frequent flood episodes in the zone. Based on this study, it can therefore be concluded that the Sudano-Sahelian Ecological Zone of Nigeria has been experiencing an increase in the annual rainfall with little recession in 1970s and 1980s, the rainfall has been very high and this has significant consequences on water resources in the zone with the zone becoming prone to flood events, erosion and sedimentation which may have adverse effect on both quantity and quality of water available for human consumption. The study therefore recommends that a study of the interactions between the ecosystems due to the distortion in the hydrology of the zone should be carried out among others.
\end{abstract}

Keywords: trend, Sudano-Sahelian, standardized anomaly index

\section{Introduction}

The concentration of greenhouse gases in the atmosphere has increased over the past few decades. This increase is expected to increase rainfall characteristics such as the rainfall amounts, intensity, duration and frequency. This is also expected to alter the pattern of rainfall (Ojoye, 2012). Climate change studies have revealed that droughts will become more rampant and extreme rainfall events more frequent if the trend is not controlled (Fredrick \& Major, 1997). Recent researches (Odekunle et al., 2008, Dami, 2008; Ojoye, 2012) have revealed that rainfall pattern over the Sudano Sahelian Ecological zone of Nigeria have shifted from the dry epochs to increasingly wet epochs with more than halve of this increase due to heavy rainfall events ( $>50 \mathrm{~mm}$ per day). The combination of dry periods interspersed with larger individual rainfall events will result in extended periods of soil moisture and variability in soil water content. These fluctuations in rainfall over Africa in General and the Sudano Sahelian Ecological Zone of Nigeria in particular are due to the prevailing circulation patterns over Africa during July/August and January. The two most apparent seasonal shifts are in pressure over the Sahara and the location of the convergence zones. The two most apparent seasonal shifts are due to changes in pressure and the location of the Inter-tropical Convergence Zone (ITCZ). In July/August, the low pressure over the Sahara lies between the NE trades, or Harmattan, and the humid monsoon flow. The convergence zones have moved southward, with the ITCZ penetrating far into the southern hemisphere. The upper air patterns also shift seasonally. In July/August, the upper-level flow is easterly over most of the continent. Imbedded in the easterlies are three jet streams, the African Easterly Jet (AEJ), the Tropical Easterly Jet (TEJ). The AEJ and TEJ are important for the development of the summer rainfall regime over northern Africa. The AEJ, in particular, 
provides energy for the development and maintenance of rain-bearing disturbances. The prevailing patterns of rainfall and its seasonality are a direct consequence of these circulation patterns. In general, rainfall is associated with the mid-latitude westerly's i.e. with the frontal systems within them and the convergence zones. Thus, the longer the season during which one of these systems dominates in a given region, the higher the mean annual rainfall in that region. Thus, the rainiest locations are the pole ward extremes, where mean annual rainfall is on the order of 800 to $1200 \mathrm{~mm}$, and the equatorial zone, where it is on the order of 1200 to $2000 \mathrm{~mm}$.

\section{Study Area}

The Sudano-Sahelian Ecological Zone (SSEZ) of Nigeria is a large ecological zone that occupies almost one-third of the total land mass of the country. The area lies between longitudes $4^{0} \mathrm{E}$ and $14^{0} \mathrm{E}$, and latitudes $10^{\circ} \mathrm{N}$ and $14^{\circ} \mathrm{N}$. It stretches from the Sokoto plains through the northern section of the high plains of Hausa land to the Chad basin (Figure 1). This ecological zone house $25 \%$ of the Nigerian population supports three-quarter of cattle population, about $75 \%$ of the goats and sheep, and almost all the donkeys, camels and horses found in the country. Major cereals such as cow peas, groundnut and cotton are the main crops grown in the region (Odekunle et al., 2008)

The climate of the zone is dominated by the influence of three major meteorological features, namely; the Tropical Maritime (mT) air-mass, the Tropical Continental (cT) air-mass, and the equatorial easterlies. The first two air-masses (mT and $\mathrm{cT}$ ) meet along a slanting surface called the inter-tropical discontinuity (ITD); the equatorial easterlies are rather erratic and relatively cool air masses from the east in the upper troposphere along the ITD. The movement of the ITD Northwards across the country between January and August, and its retreat from the Southern fringe of the Sahara desert, after August, causes much of Nigeria to experience seasonal rainfall (Ojoye, 2012) Within the $\mathrm{mT}$ air mass is enclosed a number of rainfall producing system such as the disturbance lines (especially the easterly waves), squall lines and the two tropospheric jet streams. Ojoye (2007) reported that it is the magnitude of these systems that influence the amount and seasonal distribution of rainfall over the region.

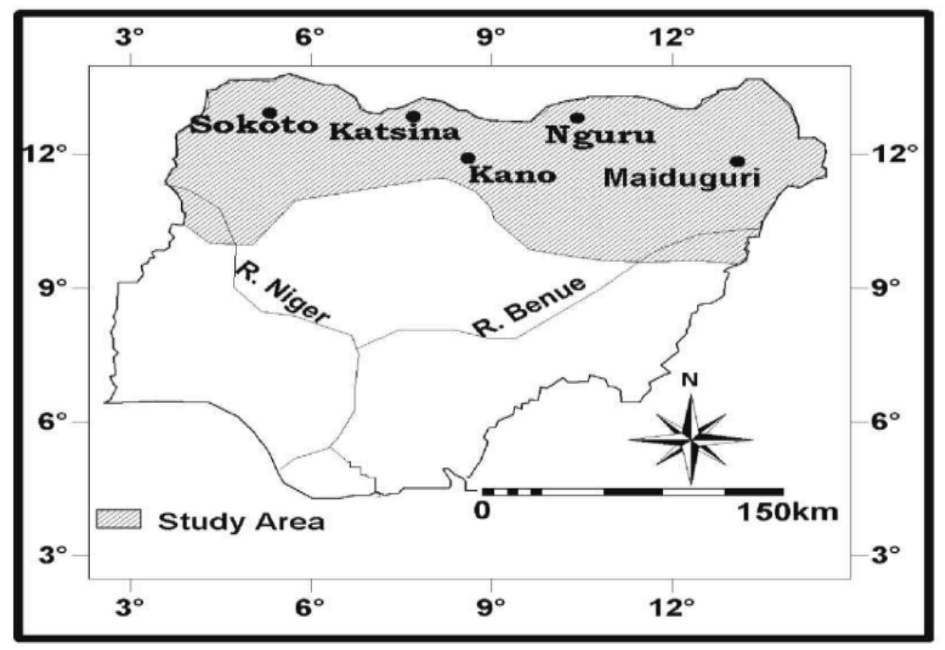

Figure 1. The Sudano-Sahelian ecological zone

Temperature in the region is high throughout the year with a mean minimum value of about $23{ }^{\circ} \mathrm{C}$ and mean maximum of about $34{ }^{\circ} \mathrm{C}$ (Ojoye, 2008). In the rainy season, temperature is fairly steady because cloudiness and humidity prevent back radiation, thus the diurnal range of temperature is relatively small, and it is about $2{ }^{\circ} \mathrm{C}$ (Oyebande, 2000). In the dry season the much back radiation is witnessed in the night and it tends to lower night temperature values. Thus, a high diurnal range of temperature sometimes as high as $12{ }^{\circ} \mathrm{C}$ is observable. Notwithstanding of temperature, the optimum temperature for growing crops and plants growth is obtainable at all periods of the year. 


\section{Methodology}

To study rainfall trends over time, four types of rainfall attributes were analyzed; changes in annual totals, changes in wet and dry season rainfalls, changes in rainfall intensity and in the frequency of rainfall events. The ten year running mean of the annual duration was calculated to reveal the trend in the duration. The period 1960 to 2009 was used for the study. This period was sub-divided into decades (1960-1969, 1970-1979, 1980-1989, 1990-1999 and 2000-2009) and their means were calculated. This was compared with the long-term mean to determine their deviation from the mean. The results were presented in Figure 2(a-h). Trends were also investigated in three sub periods of thirty (30) years (which represents a climate normal). For the purpose of this study, the rain year was divided into two periods viz: The dry season and wet season. The months of October to April/May was used to constitute the dry season depending on the latitude of the station and the rest of the year as wet season. The trend in dry and wet season rainfall was also computed.

In identifying variation and fluctuations in the rainfall values, the standardized rainfall anomaly index (SRAI) according to Katz and Glantz (1986) was used. The index is most commonly used for regional climate change to examine the changes that might have taken place in the rainfall distribution over the period 1960-2009. This index has been found to be effective for rainfall variability in Niger basin area (Babatolu, 1998). The SRAI was calculated for the individual station using the following equation:

$$
X_{i j}=\frac{i}{N_{j} \sum_{1}^{N_{j}}\left(r_{i j}-r_{i}\right) \sigma_{i}}
$$

Where:

$\mathrm{X}_{\mathrm{ij}}=$ rainfall departure for $\mathrm{jth}$ year;

$\mathrm{r}_{\mathrm{ij}}=$ the year's rainfall total at station $\mathrm{I}$;

$\mathrm{r}_{\mathrm{i}}=$ the mean of station i's total for the base period;

$\sigma_{i}=$ the standard deviation of station i's totals for the base period;

$\mathrm{N}_{\mathrm{j}}=$ number of years when data are available.

The annual rainfall, rain-day, daily rain of different intensities, dry and wet season rainfall were also analyzed for trends. The Spearman rank statistics was used to test for non- randomness in the series. The Spearman rank correlation is given as:

$$
R_{s}=1-\frac{6 \sum d^{2}}{N^{3}-N}
$$

Where

$\mathrm{d}=$ the difference in rank in each pair values;

$\mathrm{N}=$ number of pairs.

Dry and wet season rainfalls were determined following Adefolalu (1998) with a view to identifying periods of significant decline. The dry season was however taken to include the months of onset and cessation of the rain and cover the period October to April/May. The wet season rainfall was taken to include the rains which fall from May/June to September depending on the latitudinal location of the station.

\section{Presentation of Results and Discussion}

During the 50 years under study (1960-2009), yearly rainfall at various stations fluctuated markedly around their long- term means. The graphs in Figures $2(\mathrm{a}-\mathrm{h})$ revealed distinct periods of short term and long-term rainfall fluctuations with period 1970s and 1980s recording unparallel long run of dry years (below long term average rainfall) at many of the stations which is more pronounced in Nguru, Sokoto, Kano and Maiduguri.

Most of the eight rainfall stations selected for the study showed that the period 1960 to 2009 contains four distinct periods when rainfall exhibited trends of particular type was most persistent. The first manifested in below long term average which occurred before the wet years of 1960s. This period varies in severity and length over the region being markedly longest and severest in most of the stations with the period 1970 to 1987 receiving about 5 percent below the long-term average. However, there were occasional respites such as in 1990 (for Kano), 1980 and 1981 for Nguru, 1988, 1990 and 1992 for Sokoto, 1971 for Dutse, 1978, 1988 and 1990 to 1993 for Katsina. At Kano (Figure 2a) the 1960s were wet except 1961 and 1965. The entire 1970s and 1980s were dry years with most 
of the years below the long-term average. 1990s and 2000 to 2009 were wet years with most of the years exhibiting more than 20 percent above the long term average. At Nguru (Figure 2b) 1960s and 1970s were dry years with the exception of 1962, 1964, 1966 and 1967 which exhibited about 5 percent above the long term average, all other years under study at the stations were wet years with the exception of 2007 and 2008.

Rainfall fluctuations in the SSEZ show diverse spatial and temporal patterns of occurrence, probably due to local influence. The most synchronous spatial patterns are the above average rainfall of the 1960s and the belowaverage of the 1970s and 1980s in this region. The wet years are more striking than the dry ones; positive departures of 30 to 40 percent are common, while departures in the dry years rarely reach 30 percent.

Trend in annual rainfall over the Sudano-Sahelian Ecological Zone of Nigeria indicated that there has been an overall increase in the annual rainfall for the entire period under study with a recession in 1970s and 1980s due to the well researched drought of 1972/73 and 1980s in the Zone. Many studies in the Sudano-Sahelian Ecological Zone of West Africa in general, and Nigeria in particular, have established a general trend in rainfall towards aridity at the drought years (Powel et al., 1999a; Nicholson, 2001; Hulme et al., 2001; Dami, 2008; Odekunle et al., 2008). Recently, however, some scenarios (based on greenhouse gas emissions) have suggested that the observed trend towards aridity will be put on hold or be reversed in the twenty-first century (Smith et al., 2000; Haarsma et al., 2005). In fact, Haarsma et al. (2005) reported that rainfall has been increasing in the Sahel region of West Africa. Based on climate data for the period extending from 1960 to 2009, the present study has confirmed that drought conditions have persisted in the Sudano-Sahelian Ecological zone of Nigeria up to 1990 and that an upward trend of rainfall was also being observed since the last episode of the 1980s drought an implication that the Sudano Sahelian Ecological one of Nigeria is getting wetter.

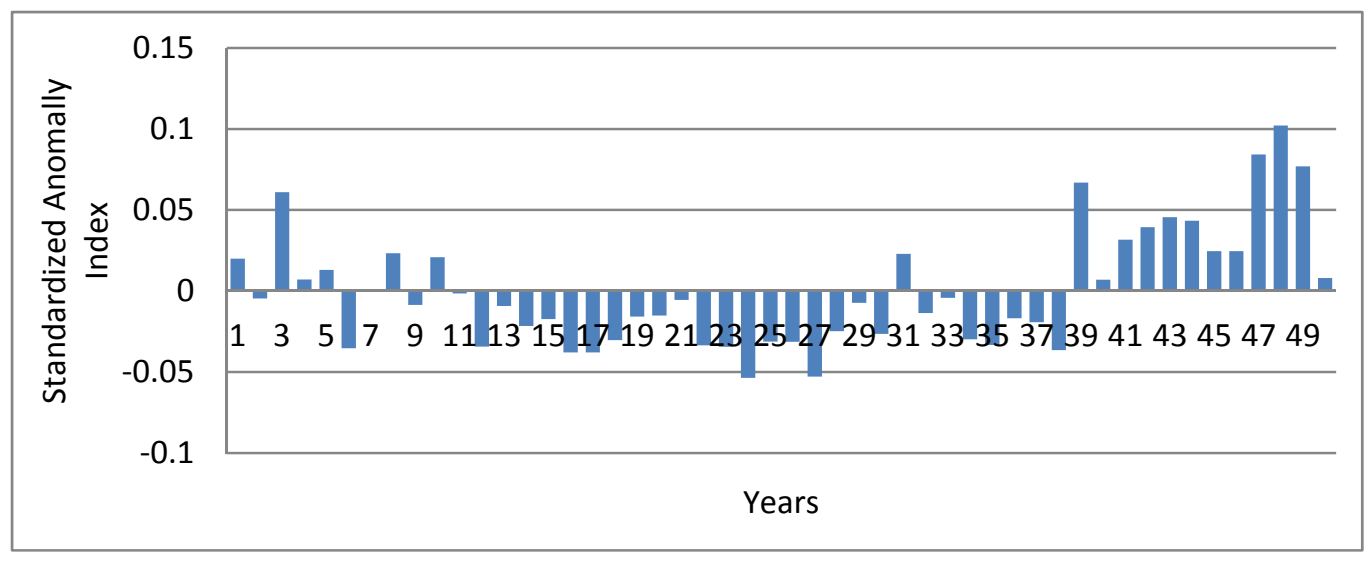

Figure 2a. Annual rainfall fluctuations for Kano (1960-2009)

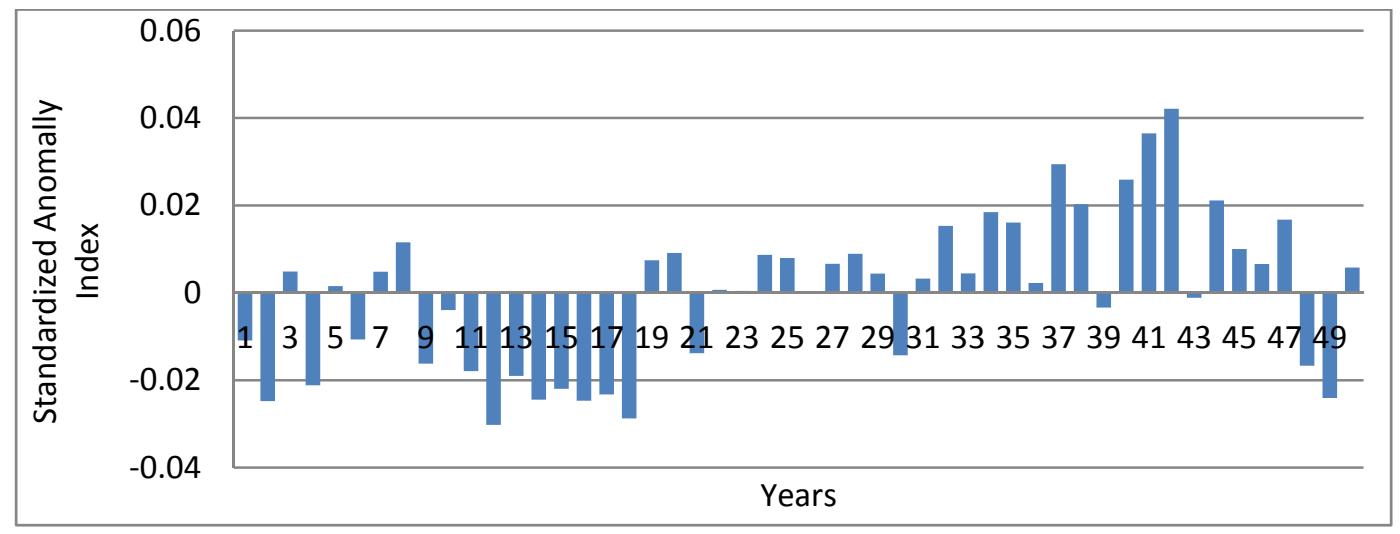

Figure 2b. Annual rainfall fluctuations for Ngure (1960-2009) 


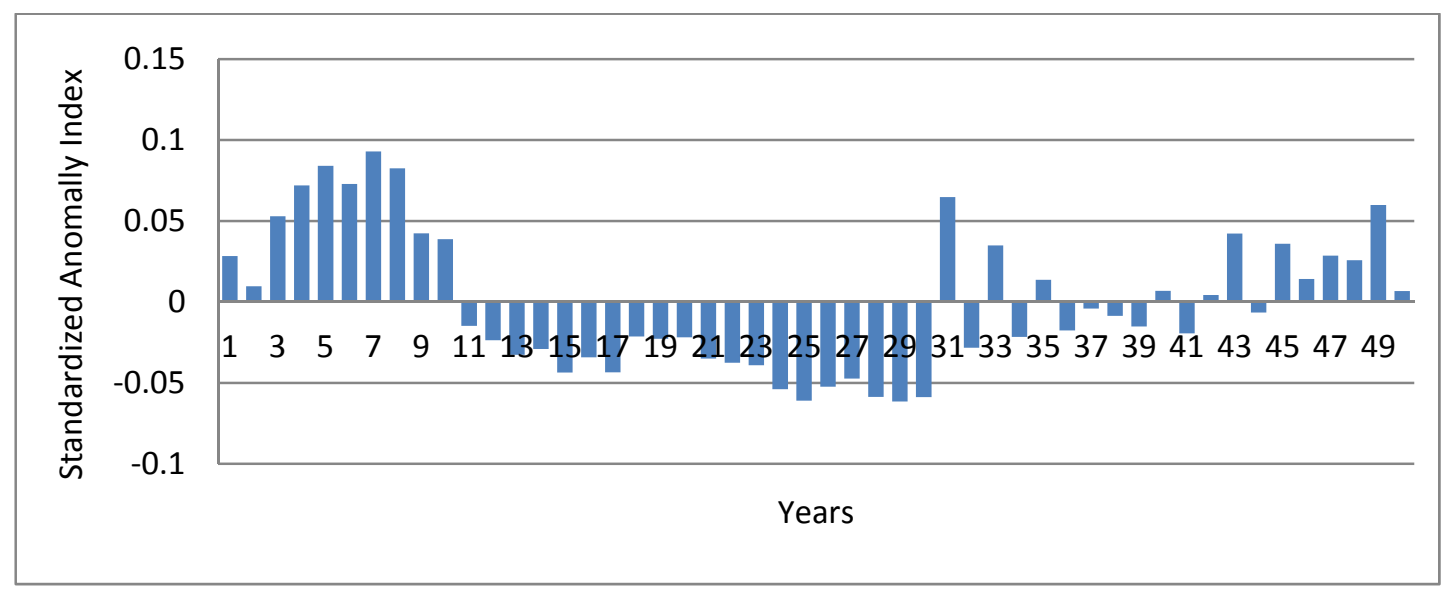

Figure 2c. Annual rainfall fluctuations for Sokoto (1960-2009)

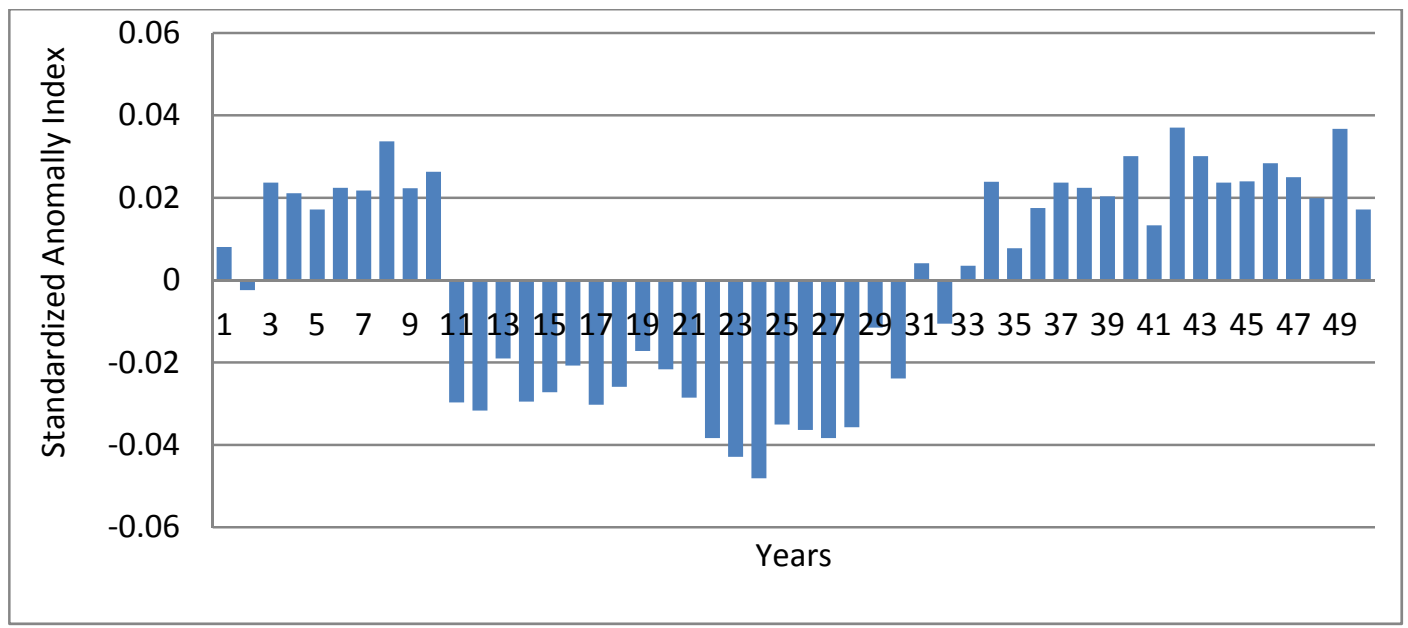

Figure 2d. Annual rainfall fluctuations for Yelwa (1960-2009)

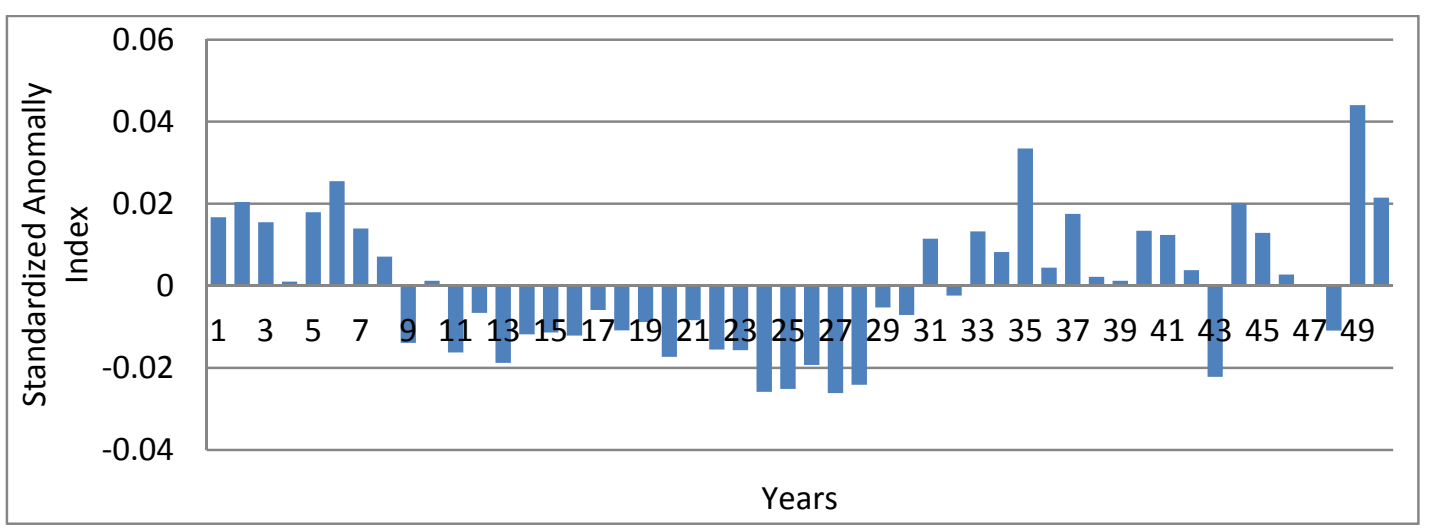

Figure 2e. Annual rainfall fluctuations for Maiduguri (1960-2009) 


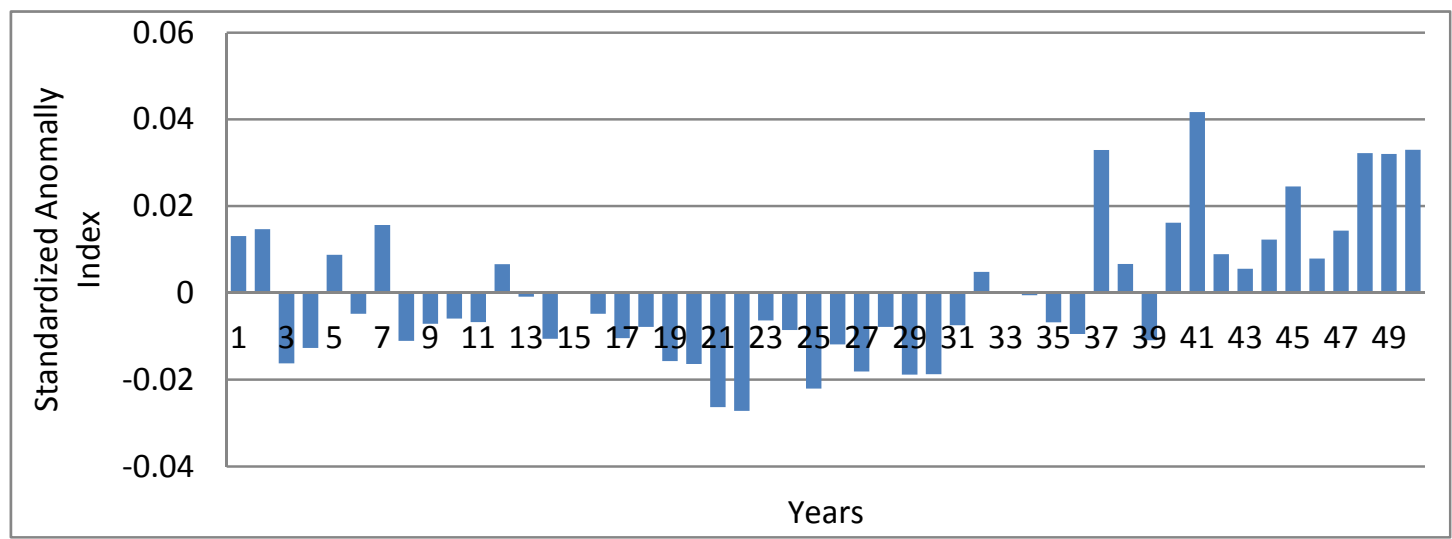

Figure 2f. Annual rainfall fluctuations for Dutse (1960-2009)

\subsection{Trends in Dry-Season Rainfalls in the SSEZ}

Trends in the dry-season rainfall series was tested using Spearman rank correlation statistics for the period 1960 to 1989,1970 to 1999,1980 to 2009 and 1960 to 2009. The trends exhibited by the series of different sub-periods and at different levels of statistical significance. The values of which were displayed in Table 1.

Table 1. Trend in dry season rainfall in the selected stations using spearman rank correlation coefficient

\begin{tabular}{lcccc}
\hline Station & $\mathbf{1 9 6 0 - 2 0 0 9}$ & $\mathbf{1 9 6 0 - 1 9 8 9}$ & $\mathbf{1 9 7 0 - 1 9 9 9}$ & $\mathbf{1 9 8 0 - 2 0 0 9}$ \\
\hline Kano & -0.105 & -0.250 & -0.008 & +0.066 \\
Nguru & +0.195 & +0.025 & +0.497 & +0.032 \\
Sokoto & +0.461 & Short Data & +0.511 & +0.370 \\
Yelwa & +0.121 & -0.604 & +0.347 & +0.476 \\
Maiduguri & -0.029 & -0.099 & +0.051 & -0.001 \\
Dutse & +0.024 & -0.041 & +0.053 & +0.055 \\
Katsina & +0.034 & -0.159 & +0.380 & +0.265 \\
\hline
\end{tabular}

The results in Table 1 shows that dry-season rainfall increased for Nguru $(+0.195)$, Sokoto $(+0.461)$, Yelwa $(+0.121)$, Dutse $(+0.024)$ and Katsina $(+0.034)$ while decline are experienced in Kano and Maiduguri in the period 1960 to 2009. There was a general decline in the dry-season rainfall for all the stations in 1960 to 1989 with a little respite at Nguru which shows an increase of +0.025 . All the stations recorded an upward trend in the period 1970 to 1999 with an exception for Kano with a negative trend. It was the same for all the stations in the period 1980 to 2009 when all the stations recorded a positive trend with a difference in Maiduguri where -0.001 was recorded. These results indicated that with the entire years under study divided into climatic sub-divisions, the period 1960 to 1989 recorded a negative trend at all the stations, the reason for this decline is not far-fetched taking into consideration the prolonged drought of 1970s and 1980s that ravaged the entire Sudano-Sahelian ecological zone of Nigeria and are widely reported in literatures.

\subsection{Trends in Wet-Season Rainfalls in the SSEZ}

The wet-season rainfall series were also examined for trends (Table 2). The results shows a strong upward trend which was observed in many of the stations with Sokoto being an exception. This general upward trend was the order of the day when trend was computed for the period 1960 to 2009. When the wet-season rainfall trend was computed for the period 1960 to 1989, six out of the seven stations considered recorded a downward trend; the implication of this particular trend for this period is the severe drought of the 1970s and 1980s experienced in the Sudano-Sahelian ecological zone of Nigeria.

The third period considered for trend was the period between 1970 to 1999 , at this period, most of the station considered recorded a positive trend. Despite the fact that drought was recorded in 1972/1973 and 1980s in the SSEZ of Nigeria, the decades that follows (1960 to 1999 and 2000 to 2009) recorded very high rainfall during the wet season, the effects of which offset the dryness of the previous decades, apparently, therefore, the high fluctuations of the annual rainfall of the midland zone of Nigeria is due mainly to the high fluctuations in 
wet-season rainfall. The increase in annual rainfall in the study area during the period 1960 to 2009 has resulted mainly from the increase in the wet-season rainfall. Babatolu (1998) and Dami (2008) examined the rainy season rainfall (April to October) in the Niger River Basin Development Authority (NRBDA) area of Nigeria ( $11^{0}$ to $18^{0} \mathrm{~N}$ ) and reported a persistent decline with little decreased progressively in the NRBDA area during the period 1931 to 1990 except in the extreme northern parts of Zaria and Yelwa and at Lokoja in the extreme southern parts.

In contrast to the positive trends which characterize the 1960 to 2009 period, the result in Table 1 show significant negative trend during the period 1960 to 2009 for dry-season rainfall for Kano and also for Yelwa, Maiduguri, Dutse and Katsina for 1960 to 1989 period.

Table 2. Trend in wet season rainfall in the selected stations in the SSEZ

\begin{tabular}{ccccc}
\hline Station & $\mathbf{1 9 6 0 - 2 0 0 9}$ & $\mathbf{1 9 6 0 - 1 9 8 9}$ & $\mathbf{1 9 7 0 - 1 9 9 9}$ & $\mathbf{1 9 8 0 - 2 0 0 9}$ \\
\hline Kano & +0.133 & -0.452 & +0.085 & +0.586 \\
Nguru & +0.257 & +0.100 & +0.621 & +0.022 \\
Sokoto & -0.021 & -0.701 & +0.124 & +0.504 \\
Yelwa & +0.096 & -0.581 & +0.557 & +0.787 \\
Maiduguri & +0.023 & -0.599 & +0.378 & +0.362 \\
Dutse & +0.202 & -0.397 & +0.088 & +0.674 \\
Katsina & +0.062 & -0.145 & +0.446 & +0.271 \\
\hline
\end{tabular}

\subsection{Characteristics of Dry and Wet-Season Rainfalls in the SSEZ}

The period 1960 to 2009 for the dry season and wet-season rainfall at the selected stations was divided into two sub-periods, 1960 to 1989 and 1960 to 2009 to investigate the secular trend in the series (Table 3). The results in Table $3 \mathrm{a}$ and $\mathrm{b}$, show that their was a substantial decline in the dry season rainfall in Kano and Maiduguri, a decrease of -22 percent and -1.69 percent respectively between the two periods.

Table 3(a). Deviation of the 1960-1989 means of dry season rainfall from 1960-2009

\begin{tabular}{lccc}
\hline Stations & $\mathbf{1 9 6 0 - 1 9 8 9}$ & $\mathbf{1 9 6 0 - 2 0 0 9}$ & \% Change \\
\hline Kano & 65.8 & 53.8 & -22.28 \\
Nguru & 73.7 & 105.9 & +30.45 \\
Sokoto & 36.8 & 54.1 & +31.98 \\
Yelwa & 150.7 & 184.0 & +18.09 \\
Maiduguri & 80.8 & 79.5 & -1.69 \\
Dutse & 74.3 & 87.8 & +15.32 \\
Katsina & 93.8 & 103.8 & +9.60 \\
\hline
\end{tabular}

Table 3(b). Deviation of the 1960-1989 means of wet season rainfall from 1960-2009

\begin{tabular}{lccc}
\hline Stations & $\mathbf{1 9 6 0 - 1 9 8 9}$ & $\mathbf{1 9 6 0 - 2 0 0 9}$ & \% Change \\
\hline Kano & 581.5 & 665.4 & +12.6 \\
Nguru & 450.8 & 515.4 & +12.5 \\
Sokoto & 699.0 & 735.9 & +5.01 \\
Yelwa & 553.8 & 645.0 & +14.14 \\
Maiduguri & 526.7 & 580.9 & +9.34 \\
Dutse & 502.6 & 571.7 & +12.09 \\
Katsina & 530.2 & 583.5 & +9.14 \\
\hline
\end{tabular}

Nguru and Sokoto recorded the highest increase of +30.45 percent and 31.98 percent respectively. There was an increase in the dry-season rainfall in five out the seven stations under consideration, the positive value corroborate a general upward trend in the annual rainfall. There was a general increase in the trend of the wetseason rainfall in all the seven stations considered with Yelwa recording the highest percentage increase of +14.14 percent while the lowest value of +5.01 percent was observed in Sokoto. This implies that Sokoto is the 
driest of all the stations considered. This trend varies from one station to another; by 12.6 percent at Kano, 12.5 percent at Nguru, 5.01 percent at Sokoto, 9.34 percent at Maiduguri and 12.09 and 9.14 percent at Dutse and Katsina respectively. For most of the station considered, the increase in annual rainfall between 1960 to 1969 and 1990 to 2009 was virtually accounted for by the increase in wet-season rainfall recorded at these stations within this time frame.

From the foregoing analyses (Tables 1 and 2) it may be deduced that the general increase in annual rainfall during the period 1960 to 2009 period was mainly due to the significant increase in wet-season rainfall during the period. This result indicates that there has been a significant change in the climate of Sudano-Sahelian ecological zone of Nigeria, the results of which was corroborated through the findings of Haarsmasen et al. (2002) and Odekunle et al. (2008) that established that rainfall has been increasing in the Sudano Sahelian ecological zone of Nigeria and that the region is getting wetter since the mid-1980s respectively.

Drastic fluctuations in the dry season rainfall will have major consequences on water supply in Sudano-Sahelian ecological zone of Nigeria. Similarly significant fluctuations in the wet-season rainfall may also have adverse consequences for water supply especially in terms of threshold demand for particular cases.

\section{Conclusion}

Rainfall variation in Sudano-Sahelian Ecological Zone of Nigeria has shown two distinct characteristics; a lower than long term average between 1970s and 1980s and an above average variation in rainfall which occurred between 1990s to 2009. The increase in rainfall over the years in the Zone has resulted in the increasing cases of flood in the entire zone and there is the likelihood that this would continue if the flood plains were not properly managed.

The study however suggested that our ability in predicting climate change and plan for mitigation of its negative consequences will go a long way in a reducing the hardship caused by the changes in the climate. There is the need for more articulate poverty alleviation strategies by the three tiers of government within the Sudano-Sahelian Ecological Zone of Nigeria as this will assist the resilience of the poor of the zone.

The negative trend in rainfall will have a devastating effect on the agriculture of the zone. To reduce this problem, the extension officers will have to work all round the clock to assist over $80 \%$ of the small scale farmers of the zone in developing new adaptation strategies that will assist in the improvement of the various agricultural practices engaged upon in the zone. It was also found to be highly important to make very good use of the over- 30 dams in the zone that are underutilized so as to enhance the agricultural production in the zone.

\section{References}

Adefolalu, D. O. (1998). Rainfall Trends in Nigeria. Theoretical and Applied Climatology, 37(1), 205-219.

Babatolu, J. S. (1998). Climate Change and its Implications for Water Supply in the Niger River Basin Development Authority Area of Nigeria. (Unpublished Ph.D Thesis) Department of Geography, University of Ilorin, Ilorin.

Dami, A. (2008). A Predictive Study of Environmental Change in the Nigeria's section of the Chad Basin. (Unpublished PhD Thesis) Obafemi Awolowo University, Ile-Ife.

Frederick, D., \& Major, R. (1997). Water Resources Planning Principles and Evaluation Criteria for Climate Change. Climatic Change, 36, 234-240.

Hansen, J., Sato, M., Nazarenko, L., Ruedy, R., Lacis, A., Koch, D., ...Christy, J. (2002). Climate Forcing in Goddard Institute for Space Studies SI2000 simulations. Journal of Geophysical Research: Atmospheres, 107(D18), ACL 2-1-ACL 2-37. http://dx.doi.org/10.1029/2001JD001143

Hulme, M., Sheard, N., \& Chilcott, C. (2001). Climate Change Scenarios for Australia. Climatic Research Unit, University of East Anglia, Norwich, United Kingdom, p. 6. Retrieved May 10, 2009, from http://www.cru.uea.ac.uk

Katz, R. W., \& Glantz, J. K. (1986). Techniques for Estimating Uncertainty in Climate Change Scenarios and Impact Studies. Climate Research, 20,167-185. http://dx.doi.org/10.3354/cr020167

Nicholson, S. E. (2001). The Nature of rainfall fluctuations in subtropical West Africa. Monthly weather period, 108(4), 473-487. http://dx.doi.org/10.1175/1520-0493(1980)108<0473:TNORFI $>2.0 . C O ; 2$

Odekunle, O. T., Andrew, O., \& Aremu, O. S. (2008). Towards a Wetter Sudano-Sahelian Ecological Zone in the Twenty-First Century Nigeria. Weather, 63(3), 66-70. http://dx.doi.org/10.1002/wea.172 
Ojoye, S. (2007). Rainfall Variability and its Influence on Maize Production in Northern Nigeria. Conference Proceedings, School of Science and Science Education, Federal University of Technology, Minna. Nigeria

Ojoye, S. (2008). Climate Change and Crop Production, Journal of Science and Technology. Federal University of Technology, Minna. Nigeria.

Ojoye, S. (2012). Climate Change Impact and Adaptation Strategies to Water Resources in the Sudano-Sahelian Ecological zone of Nigeria. (An Unpublished $\mathrm{PhD}$ thesis of the Department of Geography and Environmental Management) University of Ilorin, Ilorin.

Oyebande, L. (1995). Effects of Reservoir Operation on the Hydrological Regime and Water Availability in Northern Nigeria. Man's Influence on Freshwater Ecosystems and Water Use (Proceedings of a Boulder Symposium, July 1995). IAHS Publ. no. 230.

Powel, S., Casey, T., Folland, C., Colman, A., \& Mehta, V. (1999a). Decadal Modulation of the Impact of ENSO on Australia. Climate Dynamics, 15, 319-324. http://dx.doi.org/10.1007/s003820050284

Smith, I. N., McIntosh, P., Ansell, T. J., Reason, C. J. C., \& McInnes, K. (2000), South-West Western Australia Rainfall and its Association with Indian Ocean Climate Variability. International Journal of Climatology, 20, 1913-1930. http://dx.doi.org/10.1002/1097-0088(200012)20:15<1913::AID-JOC594>3.0.CO;2-J

\section{Copyrights}

Copyright for this article is retained by the author(s), with first publication rights granted to the journal.

This is an open-access article distributed under the terms and conditions of the Creative Commons Attribution license (http://creativecommons.org/licenses/by/3.0/). 